\title{
Evaluation of Patients with Spontaneous Pneumothorax Secondary to Viral Pneumonia in Pediatric Intensive Care in 2018
}

\section{Yılında Çocuk Yoğun Bakım Yatışı Gerektiren ve Viral Pnömoniye Bağlı Spontan Pnömotoraks Gelişen Olguların Değerlendirilmesi}

\author{
Dilara Ceylan', Ebru Azapağası², Mutlu Uysal YazıcI², İsmet Faruk Özgüner ${ }^{3}$ \\ ${ }^{1}$ Clinic of Pediatrics, Health Sciences University Dr. Sami Ulus Obstetrics, Ankara, Turkey \\ ${ }^{2}$ Clinic of Pediatric Intensive Care and Pedaitrics Training and Research Hospital, Ankara, Turkey \\ ${ }^{3}$ Clinic of Pediatric Surgery and Pedaitrics Training and Research Hospital, Ankara, Turkey
}

\section{Cite this article as: Ceylan D, Azapağası E, Yazıcı MU, Özgüner iF. Evaluation of Patients with spontaneous pneumothorax secondary to viral pneumonia in pediatric} intensive care in 2018. J Pediatr Inf 2019;13(3):e121-e125.

\begin{abstract}
Objective: The aim of this study was to evaluate the clinical findings of patients with spontaneous pneumothorax secondary to viral pneumonia who were admitted to our pediatric intensive care unit in 2018 and to contribute to the monitoring of this rare condition.
\end{abstract}

Material and Methods: Patients, who were admitted to our hospital between January 2018-December 2018 and developed spontaneous pneumothorax secondary to viral pneumonia, were evaluated retrospectively. Age, sex, cigarette smoke exposure, exposure to an individual with upper respiratory tract infection, pneumonia agent, pneumothorax time, treatment for pneumothorax, duration of invasive or noninvasive mechanical ventilation, duration of intensive care unit stay and clinical status at time of discharge were recorded.

Results: Six hundred fifty-two patients were admitted to the pediatric intensive care unit between January 2018-December 2018, and 230 of them were hospitalized for pneumonia and $3 \%$ of the patients with pneumonia had spontaneous pneumothorax. The age range was 42 days to 28 months. Causes for pneumonia were detected as respiratory syncytial virus, influenza, rhinovirus and Pseudomonas aeruginosa. Five of the patients had tube thoracostomy, other patients were monitored with $100 \%$ oxygen. Three patients required invasive mechanical ventilation. One patient died because of the underlying fatty acid oxidation disorder, 7 patients had complete recovery.
Öz

Giriş: Bu yazıda 2018 yılında merkezimize başvuran ve çocuk yoğun bakım yatışı gerektiren viral pnömoniye bağlı spontan pnömotorakslı olguların klinik değerlendirilmesi yapılarak bu nadir durumun izleminde literatüre katkıda bulunması amaçlanmıştır.

Gereç ve Yöntemler: Çalışmada Ocak 2018-Aralık 2018 tarihleri arasında hastanemiz çocuk yoğun bakım ünitesinde viral pnömoniye bağlı spontan pnömotoraks gelişen hastalar geriye dönük olarak incelendi. Tüm hastaların başvuru yaşı, cinsiyet, sigara içen bireyle teması, üst solunum yolları enfeksiyonu teması, pnömoni etkeni, pnömotoraks zamanı, pnömotoraksa yönelik verilen tedavi, invaziv veya noninvaziv mekanik ventilasyonda kalma süresi, yoğun bakım yatış süresi ve taburculuk anındaki klinik durumları kaydedildi.

Bulgular: Ocak 2018-Aralık 2018 tarihleri arasında çocuk yoğun bakım ünitesine yatırılan 652 hastanın 230'unun pnömoni nedeniyle yatırıldığı ve bunların \%3'ünde viral pnömoniye bağlı spontan pnömotoraks geliştiği tespit edildi. Yaş dağııımı 42 gün ile 28 ay arasındaydı. Pnömoni etkenleri olarak respiratuvar sinsityal virüs influenza $A$, rinovirüs ve rinovirüs ile Pseudomonas aeruginosa saptandı. Beş hastaya tüp torakostomi takılırken, diğer hastalar \%100 oksijen desteği ile izlendi. Üç hastada invaziv mekanik ventilasyon ihtiyacı oldu. Bir hasta altta yatan yağ asiti oksidasyon defekti nedeniyle eksitus olurken, diğer yedi hastada tam iyileşme gözlendi.

Correspondence Address/Yazışma Adresi

Dilara Ceylan

Sağlık Bilimleri Üniversitesi, Dr. Sami Ulus Kadın Doğum,

Çocuk Sağlığı ve Hastalıkları Eğitim ve Araştırma Hastanesi,

Çocuk Sağlığı ve Hastalıkları Kliniği,

Altındağ, Ankara-Türkiye

E-mail: mddilaradag@gmail.com

Received: 17.04.2019 
Conclusion: It should be kept in mind that spontaneous pneumothorax is a rare condition in pediatric patients, which increases mortality and morbidity. It may occur as a complication of viral pneumonias in early childhood and extend the duration of intensive care stay. Multicenter studies should be planned to determine risk factors, follow-up and treatment options for spontaneous pneumothorax.

Keywords: Spontaneous pneumothorax, viral pneumonia, pediatrics

\section{Introduction}

Pneumothorax is a condition defined as the non-pulmonary accumulation of air or gas in the thorax and is very rarely encountered in the pediatric patient population. Pneumothorax incidence in children is 5-6/10.000, and tachycardia, hypotension, cyanosis, and reduction in respiratory sounds are observed in physical examination (1). Pneumothorax is divided into two groups as spontaneous and secondary to trauma. Pneumothorax secondary to trauma occurs after a blunt or penetrating trauma to the chest and is monitored through interventions made on the chest wall for diagnosis and treatment purposes (central venous catheterization, thorasynthesis, cardiopulmonary resuscitation, and etc.) and through mechanical ventilation (MV). Spontaneous pneumothorax (SP) is also divided into two groups as primary and secondary. While a reason for the air leak cannot be found in primary SP, conditions presenting with secondary SP can be classified as primary lung diseases like asthma and cystic fibrosis, collagen tissue diseases, infections, malignancies, and foreign object aspiration (2). However, SP frequency is not known in particularly early childhood and the fact that there is no consensus on its follow-up makes the monitoring of the cases rather difficult (3). The aim of this study was to evaluate the clinical findings of patients with spontaneous pneumothorax secondary to viral pneumonia who were admitted to our pediatric intensive care unit in 2018 and to contribute to the monitoring of this rare condition.

\section{Materials and Methods}

\section{Design of the Study}

The records of the patients admitted to the pediatric intensive care unit of our hospital between January 2018 and December 2018 were retrospectively reviewed following the ethics committee approval of our hospital. Age, sex, cigarette smoke exposure, exposure to an individual with upper respiratory tract infection, pneumonia agent, pneumothorax time, treatment for pneumothorax, duration of invasive or noninvasive mechanical ventilation, duration of intensive care unit stay and clinical status at time of discharge were recorded.

\section{Inclusion and Exclusion Criteria to the Study}

Patients with SP secondary to viral pneumonia were included into the study. Patients admitted for traumatic pneu-
Sonuç: Pediatrik hasta grubunda oldukça nadir görülen, mortalite ve morbiditeyi arttıran bir durum olan spontan pnömotoraksın erken çocukluğu döneminde viral pnömonilerin bir komplikasyonu olarak karşımıza çıkabileceği ve yoğun bakım yatış süresini uzatabileceği akılda tutulmalıdır. Risk faktörlerinin belirlenmesi, izlem ve tedaviye karar vermede çok merkezli daha büyük çalışmalar planlanmalıdır.

Anahtar Kelimeler: Spontan pnömotoraks, viral pnömoni, pediatri

mothorax (central venous catheter insertion complication, post-thorasynthesis intervention, post-blunt or penetrating trauma, secondary to resuscitation, and etc.) and followed for primary SP or patients developing pneumothorax while being followed with the diagnosis of acute respiratory failure and monitored on invasive $\mathrm{MV}$ due to high pressure and oxygen concentration (PEEP: $>10 \mathrm{cmH}_{2} \mathrm{O}, \mathrm{P}_{\text {peak }}:>35 \mathrm{cmH}_{2} \mathrm{O}, \mathrm{FiO}_{2}:>$ $80 \%$, average pressure: $>16 \mathrm{cmH}_{2} \mathrm{O}$ and tidal volume: $>9 \mathrm{~mL}$ / kg) were excluded.

Pneumonia: It is defined as the inflammation caused commonly by bacteria and viruses in lung parenchyma (including the pleura, ligament, air way, alveola and vascular structures). Diagnostic criteria of pneumonia in children include physical examination findings of acute respiratory failure such as tachypnea (respiratory rate /min; 0-2 months > 60/min, 2-6 months $>50 / \mathrm{min},>6$ months $>40 / \mathrm{min})$, suprasternal, intercostal, and subcostal retractions, moaning, and nasal flaring, change in mental status and saturation without oxygen being $<90 \%$ (4). Patients complying to these criteria in the study were accepted as pneumonia.

Viral pneumonia: Findings in favor of viral pneumonia comprise of fever $<39^{\circ} \mathrm{C}$, white blood cell count $<15.000$ and low acute phase reactants accompanied by upper respiratory tract infection findings; presence of diffuse bilateral auscultation; and observation of bilateral interstitial involvement in lung graphy. Diagnosis is established by clinical and physical examinations followed by the running of the swab sample of the agent taken by cotton swabs from the lateral and posterior regions of the pharynx wall by the microbiology laboratory with respiratory tract viral panel polymerase chain reaction (PCR) method (5). Patients with these clinical criteria were assessed as viral pneumonia.

Statistical methods: Research data were analyzed by SPSS 23.0 statistical package program. Descriptive statistics were presented as mean, median ( $\min , \max$ ), frequency distribution and percentage.

\section{Results}

It was found out by this study that 652 patients were admitted to the pediatric intensive care unit between January 2018 and December 2018. It was detected that 35\% $(n=230)$ of all admissions was due to pneumonia, and MV duration was found as $8.3 \pm 2$ days and length of intensive care unit stay as average 
$7.6 \pm 1.2$ days. The number of patients developing SP secondary to viral pneumonia was eight (Figure 1). Table 1 shows the demographics of the patients developing SP. While the number of females and males were equal in these patients, age range distribution was between 42 days and 28 months and $75 \%$ were under one year of age $(n=6) .37 \%$ of the patients had history of contact with a smoker and $75 \%$ had history of contact with an individual with familial URTI. One of the patients was referred to our hospital with a preliminary diagnosis of metabolic disease, one with sepsis, hyponatremic seizure and pneumonia diagnoses, and four others had received pneumonia diagnosis and referred to our hospital due to severe respiratory distress. Two patients were examined in our outpatient clinic and were admitted to the intensive care unit because of respiratory distress. Viral respiratory tract panel was worked on PCR and respiratory syncytial virus (RSV) was detected in three patients, influenza A in one, and rhinovirus in one patient. While rhinovirus was confirmed in the nasopharynx swab sample, Pseudomonas aeruginosa produced in the bronchoalveolar lavage culture. Due to lack of kits at the referral time of two patients, the agent could not be confirmed; however, viral pneumonia was considered primarily due to the absence of fever, absence of white blood cell and C-reactive protein (CRP) elevation, and visualization of
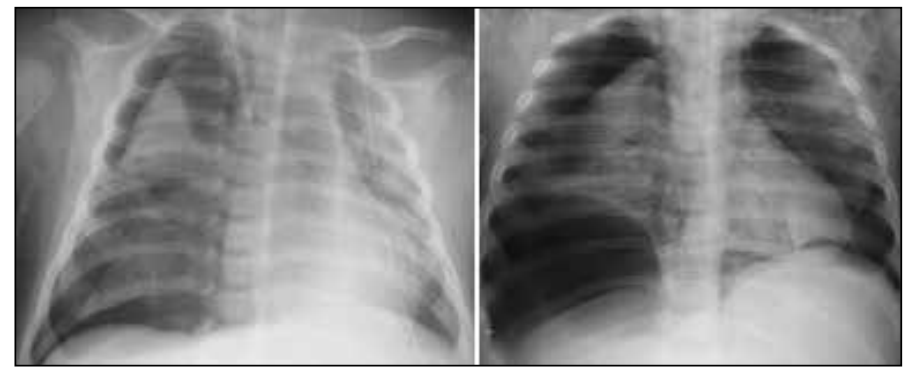

Figure 1. Some of the cases with SP (cases 5 and 7). bilateral interstitial involvement in lung graphy. Pneumothorax development in the cases was detected on the median 3.1 day $(\min =1, \max =7)$ of intensive care admission. While $62 \%$ of the patients underwent tube thoracostomy (Figure 2), others were monitored with $100 \%$ oxygen support (Figure 3). Invasive me-

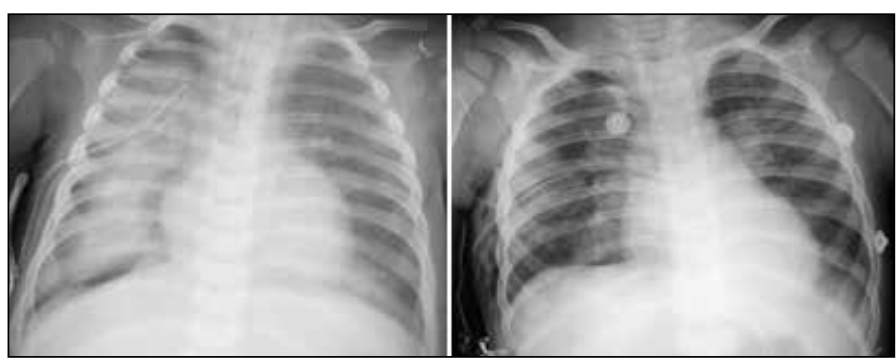

Figure 2. Some of the cases in whom tube thoracostomy was performed (cases 3 and 6).

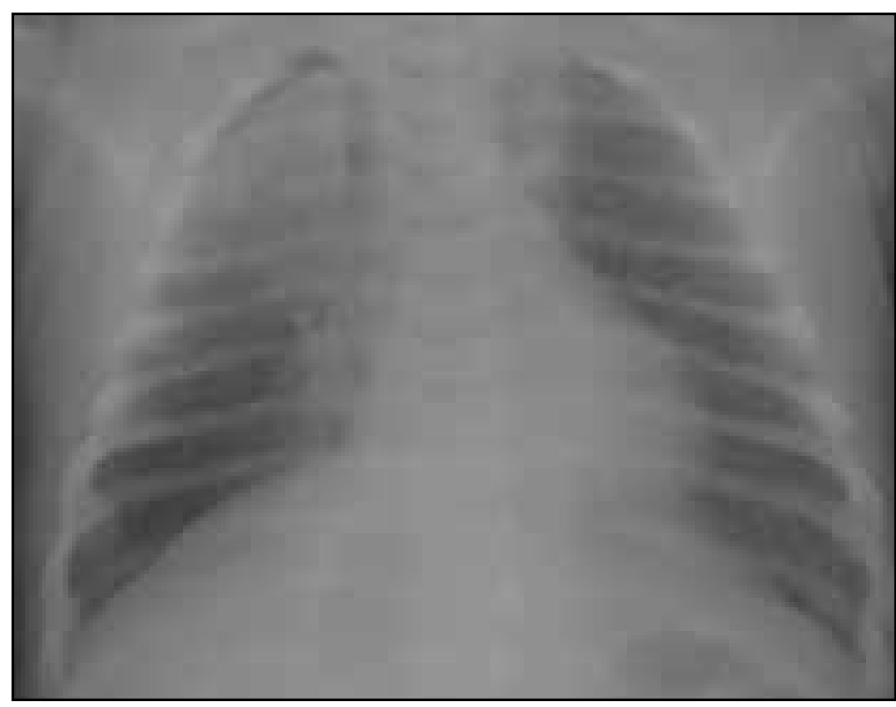

Figure 3. Example of a case on non-invasive ventilation support (case 1).

Table 1. Demographics of the cases with spontaneous pneumothorax secondary to viral pneumonia

\begin{tabular}{|c|c|c|c|c|c|c|c|c|c|c|}
\hline & Age & Sex & $\begin{array}{c}\text { Cigarette } \\
\text { smoke } \\
\text { exposure }\end{array}$ & $\begin{array}{c}\text { URTI } \\
\text { exposure }\end{array}$ & $\begin{array}{c}\text { Pneumonia } \\
\text { agent }\end{array}$ & $\begin{array}{l}\text { SP time } \\
\text { (day) }\end{array}$ & $\begin{array}{c}\text { SP } \\
\text { treatment }\end{array}$ & $\begin{array}{c}\text { Ventilation/ } \\
\text { day }\end{array}$ & $\begin{array}{l}\text { ICU } \\
\text { stay }\end{array}$ & Discharge \\
\hline Case 1 & 42 days & Male & No & Yes & Rhinovirus & 3 & $\% 100$ oxygen & NIV/5 days & 9 & Full recovery \\
\hline Case 2 & 44 days & Female & Yes & No & RSV & 6 & \%100 oxygen & NIV/ 8 days & 12 & Full recovery \\
\hline Case 3 & 6 months & Female & No & Yes & No kit & 2 & $\begin{array}{c}\text { Tube } \\
\text { thoracostomy }\end{array}$ & IV/9 days & 9 & Exitus \\
\hline Case 4 & $\begin{array}{c}3 \text { months } \\
10 \text { days }\end{array}$ & Female & Yes & No & Influenza A & 7 & \%100 oxygen & NIV/47days & 47 & Full recovery \\
\hline Case 5 & 47 days & Male & No & Yes & RSV & 2 & $\begin{array}{c}\text { Tube } \\
\text { thoracostomy }\end{array}$ & $\begin{array}{l}\text { IV/7 days NIV/ } \\
\text { 13days }\end{array}$ & 20 & Full recovery \\
\hline Case 6 & 28 days & Male & Yes & Yes & RSV & 1 & $\begin{array}{c}\text { Tube } \\
\text { thoracostomy }\end{array}$ & NIV 9days & 28 & Full recovery \\
\hline Case 7 & $\begin{array}{c}5 \text { months } \\
20 \text { days }\end{array}$ & Female & No & Yes & $\begin{array}{l}\text { Rhinovirus + } \\
\text { P. aeruginosa }\end{array}$ & 2 & $\begin{array}{c}\text { Tube } \\
\text { thoracostomy }\end{array}$ & IV 10 days & 20 & Full recovery \\
\hline Case 8 & 26 months & Male & No & Yes & No kit & 2 & $\begin{array}{c}\text { Tube } \\
\text { thoracostomy }\end{array}$ & NIV/10 days & 12 & Full recovery \\
\hline
\end{tabular}

URTI: Upper respiratory tract infection, SP: Spontaneous pneumothorax, RSV: Respiratory syncytial virus, NIV: Non-invasive mechanical ventilation, IV: Invasive mechanical ventilation, ICU: Intensive care unit. 
chanical ventilation was required in three patients. While two patients needed invasive MV support due to respiratory distress that developed after pneumothorax, one patient was referred with the preliminary diagnosis of metabolic disease and MV support was given due to severe metabolic acidosis. While the patient was followed with low pressure and tidal volume (PEEP: $5 \mathrm{cmH}_{2} \mathrm{O}$, PIP: $15 \mathrm{cmH}_{2} \mathrm{O}, \mathrm{FiO}_{2}: 40 \%$, average pressure: $10 \mathrm{cmH}_{2} \mathrm{O}$, tidal volume: $6 \mathrm{~mL} / \mathrm{kg}$ ), pneumothorax developed. It was seen that non-invasive mechanical ventilation support was required five days the shortest and 47 days the longest. Intensive care unit stay of the cases was 9 days the shortest and 47 days the longest. While one patient died due to underlying fatty acid oxidation defect, full recovery was reached in the other seven patients.

\section{Discussion}

Pneumothorax is a medical emergency for every age group. Early diagnosis and appropriate intervention are crucial since length of intensive care unit stay increases mortality and morbidity (6). While traumatic pneumothorax secondary to mechanical ventilation develops during the neonatal period, SP is more widely seen after this period and mean age range is 13.8-15.9 years $(7,8)$. Male predominance is present in adult and adolescent studies; however, sex and prevalence are not known under the age of nine (9). Some clinical features of patients with SP, which is rarely seen in children, were presented in this study. It was seen that the majority of the patients included into our study was under the age of one and no sex predominance was established. There is a distinct relation between SP prevalence and smoking in adults. However, a similar but much lower prevalence was detected in adolescents that smoke. Nevertheless, due to the fact that cigarette smoke exposure creates predisposition to bronchiolitis in much younger age groups, it is considered to be interrelated to SP but clear evidence has not been found yet (10-12). Our study confirmed that one third of our patients was exposed to cigarette smoke by family members, but since this condition suggests that cigarette smoke cannot be a parameter in SP development on its own, studies with much larger populations are needed to evaluate statistical significance. Similarly, even though life in a crowded habitat and contact with an individual with URTI are risk factors for bronchiolitis/viral pneumonia, their relation with SP is not known (13). We detected that two thirds of our patients came in contact with family members with URTI but their URTI agents was not known and clear evidence could not be provided for us. In a review assessing SPs secondary to viral pneumonia, the authors have stated that there are 13 different cases on the subject and the largest series is that of Sherman and colleagues who conducted a retrospective study (14). In that study of a ten-year period, six SP cases under the age of one were detected and the underlying reasons were found to be three pneumonia, two congenital malformation and one febrile convulsion (15). In our patient group with SP, all patients received pneumonia diagnosis, one patient had fatty acid oxidation defect and one had accompanying sepsis. Pneumonia in children under the age of five is most frequently observed with viral agents and the principal ones include RSV, influenza A and B virus, human metapneumovirus, and parainfluenza (16). Few cases have been reported in the literature showing severe pneumonia-inducing RSV and influenza virus to cause SP in children under the age of two $(15,17-18)$. Similar to the literature, three patients in our study had RSV and one had influenza A virus.

Rhinovirus, which is normally a URTI agent and known to have a moderate course, was confirmed in one patient and rhinovirus and P. aeruginosa association was found in one. Even though it is known that rhinovirus leads to pneumonia in patients with and underlying disease like bronchopulmonary dysplasia and cystic fibrosis, severe pneumonia cases with complications have not been reported in children (19). This condition is indicative of the fact that we need to keep in mind a rare agent like rhinovirus in children presenting with SP secondary to viral pneumonia. While three patients developing pneumothorax secondary to viral pneumonia were monitored with invasive mechanical ventilation, five were monitored with non-invasive mechanical ventilation (high flow nasal cannula). Only one patient developed pneumothorax under invasive MV and the other two patients were intubated and put on invasive MV since respiratory distress increased in these patients. In the event of barotrauma (mean pressure $>16 \mathrm{cmH}_{2} \mathrm{O}$ ) and volutrauma (tidal volume: $>10 \mathrm{~mL} / \mathrm{kg}$ ) secondary to $\mathrm{MV}$, traumatic pneumothorax can be observed (20). However, mean pressure and tidal volume of our patient on invasive $\mathrm{MV}$ were $10 \mathrm{cmH}_{2} \mathrm{O}$ and 6-8 mL/ $\mathrm{kg}$, respectively. Since these values are not significant in terms of traumatic pneumothorax development, SP secondary to viral pneumonia was considered in our patient. There are no guidelines in the monitoring of SP in children and with no definitive treatment method, there are only different treatment options such as observation, observation with $100 \%$ oxygen, needle aspiration and tube thoracostomy (21). It was observed in our intensive care unit that the management of all SP cases was evaluated on the grounds of their own clinical status and treated accordingly. While five patients underwent tube thoracostomy, all patients received oxygen therapy with $100 \% \mathrm{FiO}_{2}$ until pneumothorax ameliorated. In a study, it has been established that length of intensive care unit stay and mortality increased in patients developing pneumothorax out of 1238 pediatric patients admitted to the intensive care unit (22). Although it was seen that length of intensive care unit stay of the cases with SP secondary to viral pneumonia was longer than that of pneumonia cases who did not develop pneumothorax in our center, a comparison could not be made because of the small sample size. 
This study wished to emphasize that SP can be encountered in early childhood as a complication of viral pneumonia, which is a very rare condition in the pediatric patient group, and its clinical features were addressed. The fact that SP can prolong length of intensive care unit stay should be kept in mind.

\section{Limitations of the Study}

Due to the fact that $\mathrm{SP}$ is rarely encountered, determination of risk factors, monitoring and treatment protocols should be investigated in multicenter studies with larger sample sizes.

Ethics Committe Approval: Ethics committee approval was received. Informed Consent: Patient concent was obtained.

Peer-review: Externally peer-reviewed.

Author Contributions: Concept - EA, MUY; Design - DC, MUY; Supervision - MUY, IFÖ; Materials - DC, EA; Data Collection and/ or Processing - DC, IFÖ; Analysis and/or Interpretation - DC, EA; Literature Review - EA, MUY; Writing - DC, MUY; Critical Review - All of authors.

Conflict of Interest: No conflict of interest was declared by the authors.

Financial Disclosure: The authors declared that this study has received no financial support.

\section{References}

1. Marx JA, Hockberger $R$, Walls $R$, et al. Rosen's emergency medicine: concepts and clinical practice. $7^{\text {th }}$ ed. Philadelphia: Mosby/Elsevier, 2010.

2. Sahn SA, Heffner JE. Spontaneous pneumothorax. N Engl J Med 2000;342:868-74.

3. Johnson NN, Toledo A, Endom EE. Pneumothorax, pneumomediastinum, and pulmonary embolism. Pediatr Clin North Am 2010;57:135783.

4. Pediatrik Akciğer Hastalıkları Çalışma Grubu. Toraks Derneği akut bronşiyolit tanı ve tedavi rehberi. Toraks Dergisi 2002;3(Ek 3):35.

5. Turner RB, Lande AE, Chase P, Hilton N, Weinberg D. Pneumonia in pediatric outpatients: cause and clinical manifestations. J Pediatr 1987;111:194-200.

6. Esteban A, Anzueto A, Frutos F, Alía l, Brochard L, Stewart TE, et al. Characteristics and outcomes in adult patients receiving mechanical ventilation: a 28-day international study. JAMA 2002;287:345-55.

7. Healthcare Cost and Utilization Project (HCUP). Kids' Inpatient Database (KID). 1997, 2000, 2003, 2006. Available at: http://www.hcup-us. ahrq.gov/kidoverview.jsp. Accessed 2010.
8. Wilcox DT, Glick PL, Karamanoukian HL, Allen JE, Azizkhan RG. Spontaneous pneumothorax: a single-institution, 12-year experience in patients under 16 years of age. J Pediatr Surg 1995;30:1452-4.

9. Poenaru D, Yazbeck S, Murphy S. Primary spontaneous pneumothorax in children. J Pediatr Surg 1994;29:1183-5.

10. Bense L, Eklund G, Wiman LG. Smoking and the increased risk of contracting spontaneous pneumothorax. Chest 1987;92:1009-12.

11. Cottin V, Streichenberger N, Gamondès JP, Thévenet $F$, Loire $R$, Cordier JF. Respiratory bronchiolitis in smokers with spontaneous pneumothorax. Eur Respir J 1998;12:702-4.

12. Lee LP, Lai MH, Chiu WK, Leung MW, Liu KK, Chan HB. Management of primary spontaneous pneumothorax in Chinese children. Hong Kong Med J 2010;16:94-100.

13. Silva C, Almeida AF, Ferraz C, Nunes T, Guedes Vaz L. Spontaneous pneumothorax with subcutaneous emphysema: a rare complication of respiratory syncytial virus infection. J Clin Med Res 2016;8:260-2.

14. Alter SJ. Spontaneous pneumothorax in infants: a 10-year review. Pediatr Emerg Care 1997;13:401-3.

15. Jain S, Williams DJ, Arnold SR, Ampofo K, Bramley AM, Reed C, et al. Community-acquired pneumonia requiring hospitalization among U.S. children. N Engl J Med 2015;372:835-45.

16. Tutor JD, Montgomery VL, Eid NS. A case of influenza virus bronchiolitis complicated by pneumomediastinum and subcutaneous emphysema. Pediatr Pulmonol 1995; 19:393-5.

17. Piastra M, Caresta E, Tempera A, Langer A, Zorzi G, Pulitano S, et al. Sharing features of uncommon respiratory syncytial virus complications in infants. Pediatr Emerg Care 2006;22:574-8.

18. Odek C, Kendirli T, Yaman A, Aldemir-Kocabas B, Ince E. A life-threatening respiratory syncytial virus infection: a previously healthy infant with bilateral spontaneous pneumothorax and acute respiratory distress syndrome. Turk J Pediatr 2013;55:539-42.

19. Chidekel A, Rosen C, Bazzy A. Rhinovirus infection associated with serious lower respiratory illness in patients with bronchopulmonary dysplasia. Pediatr Infect Dis J 1997;16:43-7.

20. International Consensus Conferences in Intensive Care Medicine: Ventilator-associated lung injury in ARDS. Am J Respir Crit Care Med 1999;160:2118-24.

21. Baldwin S, Terndrup T. Tube thoracostomy and related procedures. In: King BR (ed). Textbook of Pediatric Emergency Procedures. $2^{\text {nd }}$ ed. Philadelphia: Lippincott Williams \& Wilkins, 2008:355-90.

22. El-Nawawy AA, Al-Halawany AS, Antonios MA, Newegy RG. Prevalence and risk factors of pneumothorax among patients admitted to a Pediatric Intensive Care Unit. Indian J Crit Care Med 2016;20:453-8. 